\title{
タマネギ収穫機の自動収穫・収納のためのトラクタの 自動並走*
}

\author{
小野山博之 $\dagger$. 菅谷 柊斗 $\ddagger$ 青山 裕也 $\ddagger$ ・藤田 大地 $\ddagger$. \\ 深尾 隆則 $\S \cdot$ 村上 則幸 9
}

\begin{abstract}
Autonomous Parallel Travelling of a Robot Tractor for Automatic Harvesting and Unloading of an Onion Harvester*
\end{abstract}

\author{
Hiroyuki Onoyama ${ }^{\dagger}$, Shuto Sugaya ${ }^{\ddagger}$, Hiroya Aoyama ${ }^{\ddagger}$, Daichi Fujita ${ }^{\ddagger}$, \\ Takanori FUKAO ${ }^{\S}$ and Noriyuki MuraKamI
}

\begin{abstract}
This paper proposes an autonomous parallel travelling system for an onion harvester and a tractor. Path following control via sliding mode control is applied to each vehicle. The velocity of the tractor is also controlled using the velocity and position of the onion harvester to maintain their relative position. As the result of experiments, the lateral, longitudinal and orientation errors between the tractor and the onion harvester were less than $0.07 \mathrm{~m}, 0.11 \mathrm{~m}$ and $2^{\circ}$, respectively. It was sufficient for the actual onion harvesting.
\end{abstract}

\section{1. 緒言}

農林水産省の統計 $[1,2]$ によると，日本人の食生活の 洋風化・外部化により，日本の野菜の消費量は年々減少 傾向にある反面, サラダやカット野菜といった簡便野菜 の一人あたりの年間購入金額は増加傾向にある。このよ うな理由から加工・業務用野菜の需要は割合として増加 傾向にある。その中でもキャベッやタマネギなどはとく に需要が高い。しかし，これらに代表される露地野菜の 栽培はわが国の主食である水稲栽培と比べ，機械化・効

* 原稿受付 2020 年 7 月 29 日

* 第 64 回システム制御情報学会研究発表講演会にて発表 (2020 年 5 月)

†立命館大学 総合科学技術研究機構 Research Organization of Science and Technology, Ritsumeikan University; 1-1-1, Noji-higashi, Kusatsu city, Shiga 525-8577, JAPAN

\#立命館大学 大学院 理工学研究科 Graduate School of Science and Engineering, Ritsumeikan University; 1-11, Noji-higashi, Kusatsu city, Shiga 525-8577, JAPAN

$\S$ 東京大学 大学院 情報理工学系研究科 Graduate School of Information Science and Technology, The University of Tokyo; 7-3-1, Hongo, Bunkyo-ku, Tokyo 113-8656, JAPAN

【 北海道農業研究センター芽室研究拠点 NARO Hokkaido Agricultural Research Center Memuro Upland Farming Research Division; 9-4 Shinseiminami, Memuro, Kasai, Hokkaido 082-0081, JAPAN

Key Words: autonomous parallel travelling, tractor, onion picker, path following control, sliding mode control.
率化が遅れており，単位栽培面積あたりに要する労力が 多い，そのうえ，日本の農業においては就業者の減少 . 高齢化による労働力の低下が著しく，露地野菜栽培のた めの労働力不足や農業生産力の低下などの深刻な問題が 生じている.

このような背景から農林水産省のプロジェクトである 革新的技術開発・緊急展開事業（うち人工知能未来農業 創造プロジェクト）の課題のひとつである本プロジェク トでは, 露地野菜栽培において最も労働力を必要とする 収穫から出荷にかけての作業を自動で行うシステムの構 築を目指し，その一環としてタマネギ自動収穫機の開発 を行っている $[3,4]$.

タマネギの収獲作業を効率化するうえでネックとなっ ているのが，収獲用コンテナの入れ替えである。これは タマネギで満杯となったコンテナを空のコンテナと入れ 替える作業であるが，コンテナ入れ替えに時間がかかる うえ，その間に収獲作業を中断することになるため，時 間的効率を下げる原因となっている。本論文ではトラク 夕にけん引されたコンテナにタマネギを収納しながら収 獲できるようタマネギ収穫機とトラクタの自動並走を行 う手法を提案する.

タマネギ収獲機とトラク夕は既存の製品に自動走行 できるように改造を施した車両を用いた。野菜の収穫で は精密な操作が求められるため, 自動化を行ううえで高 精度な自己位置同定が必要となる。高精度な位置測定 が可能であり，農業用ロボットの自動化に利用されてい る RTK-GNSS[5,6] を用いた. RTK-GNSS をそれぞれ 
2 基搭載し，位置および方位情報を得た。位置情報を基 にした参照経路を生成し，その経路に追従した操舵制御 を行うことで，自動並走の実現を目指す。経路追従手法 には，自動車や農業機械の自動走行で実績のある経路追 従制御 $[7,8]$ を基にした制御手法を用いる.

本論文では，RTK-GNSS から得た車両の位置情報を 基に生成した経路への追従制御（操舵制御）の実装手法 と，その有効性の検証を目的として行った実機実験の結 果について述べる.

\section{2. 自動並走システム}

地面の泥濘や凹凸などといった走行環境から受ける外 乱や，車両のモデル化誤差などを考慮することで，精度 が向上する可能性があると言及されていることから [3], 外乱にロバストであるスライディングモード制御を用い た。 トラクタとタマネギ収穫機はそれぞれの生成経路に 対してスライディングモード制御による追従制御を行う. タマネギ収穫機の経路追従制御とトラクタのタマネギ収 穫機と並走するための経路追従・車間距離制御について 述べる。

\section{1 経路追従制御法}

経路追従制御は仮想的に設けられた参照車両が走行す る参照経路に実車両を追従させる制御である。実車両の 状態を $q=[x, y, \theta]^{T}$, 参照車両の状態を $q_{r}=\left[x_{r}, y_{r}, \theta_{r}\right]^{T}$ とすると, 運動学モデルはそれぞれ (1) 式および (2) 式 のようになる。 Kanayama らの追従制御法 [9] を基に， 参照車両から実車両をみたときの相対誤差を用いて経路 追従制御を行う. Fig. 1 に誤差の取り方を示す. $e_{1}, e_{2}$, $e_{3}$ はそれぞれ縦偏差，横偏差および迴頭角偏差で，それ ぞれ進行方向, 左方向, 左回りを正とする.

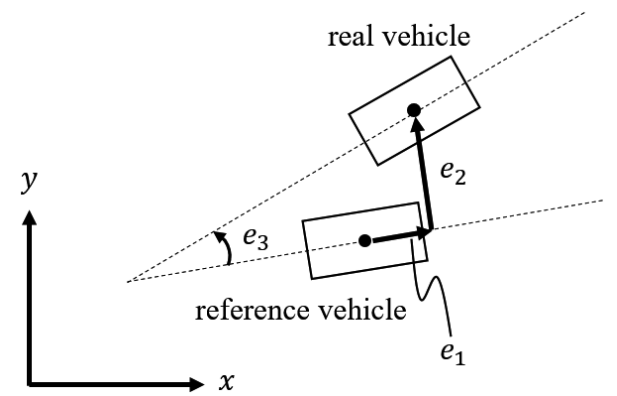

Fig. 1 Definition of path following error

$$
\begin{aligned}
& \frac{d}{d t}\left[\begin{array}{l}
x \\
y \\
\theta
\end{array}\right]=\left[\begin{array}{cc}
\cos \theta & 0 \\
\sin \theta & 0 \\
0 & 1
\end{array}\right]\left[\begin{array}{l}
v \\
\omega
\end{array}\right] \\
& \frac{d}{d t}\left[\begin{array}{l}
x_{r} \\
y_{r} \\
\theta_{r}
\end{array}\right]=\left[\begin{array}{cc}
\cos \theta_{r} & 0 \\
\sin \theta_{r} & 0 \\
0 & 1
\end{array}\right]\left[\begin{array}{l}
v_{r} \\
\omega_{r}
\end{array}\right]
\end{aligned}
$$

ここで， $v, \omega, v_{r}, \omega_{r}$ は，それぞれ実車両と参照車両 の速度および角速度である。これらの相対誤差は以下の
ようになる。

$$
\left[\begin{array}{l}
e_{1} \\
e_{2} \\
e_{3}
\end{array}\right]=\left[\begin{array}{ccc}
\cos \theta_{r} & \sin \theta_{r} & 0 \\
-\sin \theta_{r} & \cos \theta_{r} & 0 \\
0 & 0 & 1
\end{array}\right]\left[\begin{array}{l}
x-x_{r} \\
y-y_{r} \\
\theta-\theta_{r}
\end{array}\right]
$$

これを時間微分すると次式を得る.

$$
\frac{d}{d t}\left[\begin{array}{l}
e_{1} \\
e_{2} \\
e_{3}
\end{array}\right]=\left[\begin{array}{c}
v \cos e_{3}-v_{r}+e_{2} \omega_{r} \\
v \sin e_{3}-e_{1} \omega_{r} \\
\omega-\omega_{r}
\end{array}\right]
$$

$\omega_{r}$ は曲率 $\rho$ を用いて $\omega_{r}=\rho v_{r}$ と書けるので, 制御入力 $v$ に任意の速度を与え, 参照車両の速度と角速度を以下 のように設定する.

$$
\begin{aligned}
& v_{r}=\frac{v \cos e_{3}}{1-e_{2} \rho} \\
& \omega_{r}=\rho \frac{v \cos e_{3}}{1-e_{2} \rho}
\end{aligned}
$$

このとき $\dot{e}_{1}=0$ であり, 参照車両の初期值は自由に決 めることができるので, $\left(v_{r}, \omega_{r}\right)$ の初期值を $(v, \omega)$ の初 期值に合わせると $e_{1}(t=0)=0$ となって $e_{1}=0$ を得る. よって (4) 式は次のようになる.

$$
\begin{aligned}
& \frac{d}{d t}\left[\begin{array}{l}
e_{1} \\
e_{2} \\
e_{3}
\end{array}\right]=\left[\begin{array}{c}
0 \\
v \sin e_{3} \\
\omega-\omega_{r}
\end{array}\right] \\
& v_{r}=v \cos e_{3}+e_{2} \omega_{r}
\end{aligned}
$$

\section{2 スライディングモード制御系の設計}

スライディングモード制御は制御入力をあらかじめ設 定した面の上下で切り換え, 状態をその切換面に拘束し たまま平衡点に滑らせる制御であり, 外乱に対してロバ ストであることが知られている. $\xi=\sin e_{3}$ と状態変換を 行い, 時間微分する.

$$
\begin{aligned}
\dot{\xi} & =\dot{e}_{3} \cos e_{3} \\
& =\left(\omega-\omega_{r}\right) \sqrt{1-\xi^{2}}
\end{aligned}
$$

状態変換後のモデルは以下のようになる.

$$
\frac{d}{d t}\left[\begin{array}{c}
e_{2} \\
\xi
\end{array}\right]=\left[\begin{array}{c}
v \xi \\
\left(\omega-\omega_{r}\right) \sqrt{1-\xi^{2}}
\end{array}\right]
$$

(10) 式においてリアプノフ関数候補 $V_{1}$ を以下のように 定義する。

$$
V_{1}=\frac{1}{2} e_{2}^{2}
$$

時間に関して微分をすると

$$
\dot{V}_{1}=e_{2} v \xi
$$

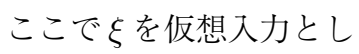

$$
\xi=-K_{s} e_{2}
$$


とする.ここで， $K_{s}$ は正の定数である．このとき，速 度 $v$ は正の数なので

$$
\dot{V}_{1}=-K_{s} v e_{2}^{2} \leq 0
$$

となり， $e_{2}$ が 0 に収束する。しかし， $\xi$ は状態量である ため, 任意ではない. そこで理想的な仮想入力との差

$$
s=\xi+K_{s} e_{2}
$$

をとり, $s=0$ を切換面とするスライディングモード制御 を行う. 正定なリアプノフ関数 $V_{s}$ を次のようにとる.

$$
V_{s}=\frac{1}{2} s^{2}
$$

時間に関して微分すると

$$
\begin{aligned}
\dot{V}_{s} & =s \dot{s} \\
& =s\left(K_{s} v \xi-\omega_{r} \sqrt{1-\xi^{2}}+\omega \sqrt{1-\xi^{2}}\right)
\end{aligned}
$$

ここで入力 $\omega を$

$$
\omega=\omega_{e q}+\omega_{l}
$$

とおく。ただし

$$
\begin{aligned}
\omega_{e q} & =\omega_{r}-\frac{K_{s} v \xi}{\sqrt{1-\xi^{2}}} \\
\omega_{l} & =-\frac{\eta \operatorname{sgn}(s)}{\sqrt{1-\xi^{2}}}
\end{aligned}
$$

とおくことで次式が成立する.

$$
\dot{V}_{s} \leq-\eta|s|
$$

上式は以下のように表すことができる。

$$
\begin{array}{r}
\frac{d V_{s}}{d t} \leq-\eta \sqrt{2 V_{s}} \\
\frac{1}{\sqrt{V_{s}}} \frac{d V_{s}}{d t} \leq-\sqrt{2} \eta
\end{array}
$$

時間積分すると以下の式が得られる.

$$
2 \sqrt{V_{s}} \leq 2 \sqrt{V_{s}(t=0)}-\sqrt{2} \eta t
$$

以上より有限時間で $\sqrt{V_{s}}=0$, つまり切換面 $s=0$ に到 達することが保証される $[10]$. このとき, 切換面 $s=0$ で (15) 式に代入すると以下が成立する.

$$
\dot{e}_{2}=-v K_{s} e_{2}
$$

上記の式より $e_{2}$ が有界であることが示される.さらに切 換面と $e_{2}$ が有界であるため, (15) 式から $\xi$ も有界であ ることがわかる。 $\omega_{l}$ は単純切換入力であり, 切換面 $s$ の 付近でスイッチング入力を加えるため, チャタリングが 生じてしまう [11]. これにより, モデルとして無視して いる高周波なダイナミクスを励起することとなる。そ己 で，次のような連続化を行い，チャタリングの発生を防 ぐことができる。ここで $\delta$ は小さい正定数である.

$$
\omega_{l}=-\eta \frac{s}{(|s|+\delta) \sqrt{1-\xi^{2}}}
$$

この連続化を行った場合，切換面の付近で入力が連続さ れる境界層とよばれる領域ができる。境界層の範囲外で は通常のスイッチング入力と同じなので, 連続化を行っ た場合も同様に入力に関するロバスト性がいえる，境界 層の範囲内でほぼ切換面近くに拘束することができるた め, 理想的なスライディングモード入力が達成される. 実際の入力は角速度ではなく操舵角を与えることから， 車両の幾何学的関係から速度, 角速度および前輪操舵角 $\phi$ の関係は前後輪の距離 $L$ を用いて次式で表される.

$$
\phi=\tan ^{-1} \frac{L}{v} \omega
$$

\section{3 速度制御}

トラクタはタマネギ収穫機と Fig. 2 のように目標と する間隔を保持しながら並走を行うために速度制御を行 う. 次式に示すように, 制御入力にはタマネギ収穫機の 速度 $v_{h}$, トラクタの速度 $v_{t}$ としてそれらの速度偏差お よびタマネギ収穫機との縦偏差 $e_{1 t h}$ をフィードバック する $\mathrm{PD}$ 制御を用いる。 $u$ はトラクタへの速度指令值で ある. タマネギ収穫機への速度指令值としては一定速度 $(0.3 \mathrm{~m} / \mathrm{s})$ を与えた。

$$
u=v_{h}-K_{p} e_{1 t h}-K_{d}\left(v_{t}-v_{h}\right)
$$

ここで $K_{p}, K_{d}$ は正定数である.

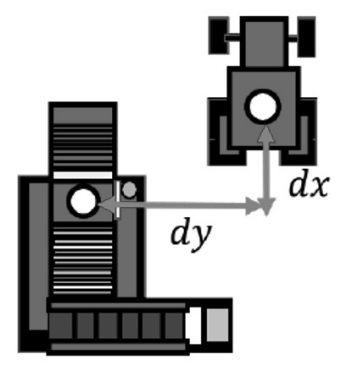

Fig. 2 Parallel travelling

\section{4 位置情報の遅延補正}

トラクタの自動並走は, 収穫機の位置, 速度情報を参 照して行っている. 収穫機側の情報を無線通信（UDP 通 信）によってトラク夕側に伝達しているが, データ処理 や通信などにより位置情報に遅延が生ずる場合がある. 位置情報に遅延が生じてしまうと縦偏差 $e_{1}$ が増大してし まうため，補正を行う必要がある。そこで RTK-GNSS から得られるタイムスタンプを用いることで補正を行う。

位置情報の取得時間のずれを $\tau$ とすると, 夕マネギ収 穫機との縦偏差 $e_{1 t h}$ は以下のようになる.

$$
\begin{aligned}
e_{1 t h}= & \left(x_{t}(t+\tau)-x_{h}(t)-x_{d i s t}\right) \cos \left(\theta_{t}-\theta_{h}\right) \\
& +\left(y_{t}(t+\tau)-y_{h}(t)-y_{d i s t}\right) \sin \left(\theta_{t}-\theta_{h}\right)
\end{aligned}
$$

ここで $x_{t}(t+\tau), y_{t}(t+\tau)$ は時刻 $(t+\tau)$ のきのトラク 
夕の自己位置, $x_{h}(t), y_{h}(t)$ は時刻 $t$ のときのタマネギ 収穫機の自己位置, $\theta_{t}, \theta_{h}$ はトラクタとタマネギ収穫機 の方位角, $x_{\text {dist }}, y_{d i s t}$ は収穫機とトラクタの目標間隔で ある。上記の式では $\tau$ だけ位置情報に誤差が生じる。そ のためタマネギ収穫機の $x, y$ 軸の速度 $v_{x_{h}}, v_{y_{h}}$ を用い ることで，以下の式のように補正を行う.

$$
\begin{aligned}
\tilde{e}_{1 t h}= & \left(x_{t}(t+\tau)-x_{h}(t)-v_{x_{h}} \tau-x_{d i s t}\right) \cos \left(\theta_{t}-\theta_{h}\right) \\
& +\left(y_{t}(t+\tau)-y_{h}(t)-v_{y_{h}} \tau-y_{d i s t}\right) \sin \left(\theta_{t}-\theta_{h}\right)
\end{aligned}
$$

これにより通信遅延による位置情報の誤差を解消する。 位置情報の遅延補正を行っていない $e_{1}$ と補正を行った $e_{1}$ を下図に示す，補正を行っていない $e_{1}$ ではピークが 表れているが，これは制御指令を送る同一周期内で，卜 ラクタの位置情報が更新されかつタマネギ収穫機の位置 情報が送られてこないために生じる。一方，補正を行っ た方ではそのようなピークは見られず，遅延補正がうま くいっていることがわかる.

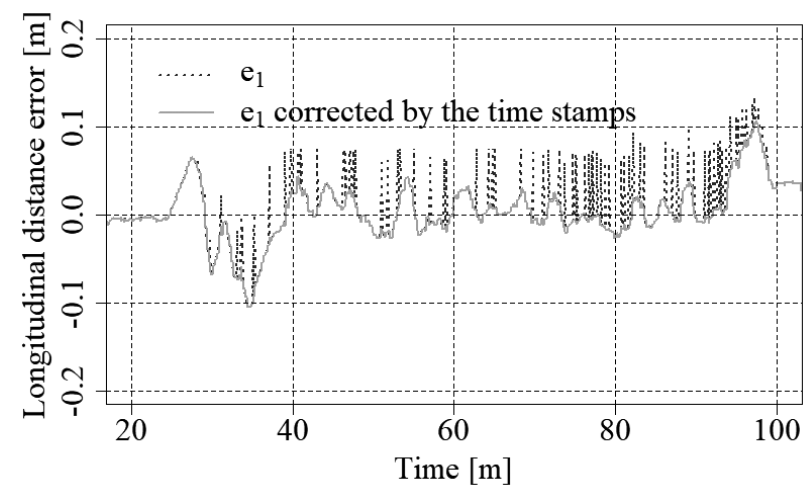

Fig. 3 Longitudinal distance error with correction and without correction

\section{5 経路設計}

タマネギ自動収穫は，収穫機がタマネギの収穫作業を 行い，収穫されたタマネギを収穫機側に取り付けたコン ベアを介してトラクタが㐮引するコンテナに収納する。

自動収穫を行う際は畧間の移動が必要となるが，トラ クタはコンテナを斢引しているため, 切返し走行が困難 である。そのため，Fig. 4のように外側の畧から渦巻状 に収穫を行う必要がある。旋回を行う枕地では並走する

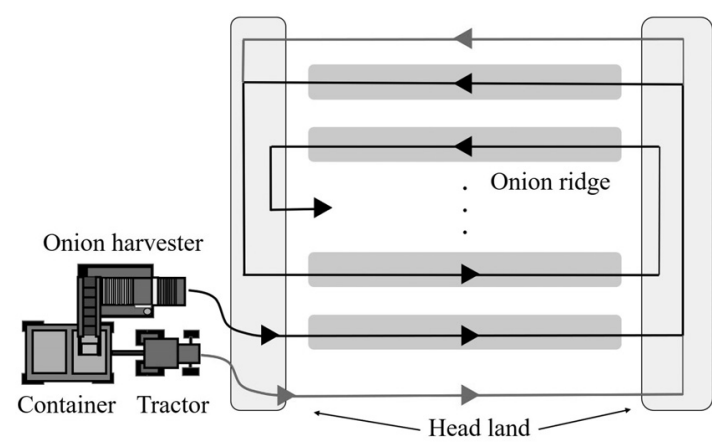

Fig. 4 Image of travelling path
必要がないため，本研究では直線部の並走について述べ る. 参照経路はFig. 5 に示すように座標点を一定間隔で 配置することで生成する，RTK-GNSSによって取得し た位置座標点の最近傍点を目標点としており，点の間隔 を $1 \mathrm{~cm}$ として参照経路を生成・追従制御を行った。

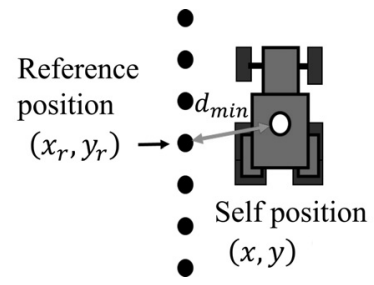

Fig. 5 Error calculation

\section{6 並走経路}

タマネギの収穫作業はほとんどが直線状に行われるた め, 収穫機の経路は直線状に生成する。経路は夕マネギ 収穫機とトラクタで別々に用意し, それぞれに対して経 路追従を行う。トラクタの並走経路は Fig. 6 に示すよう に，収穫機の経路を目標間隔分移動したものとしている.

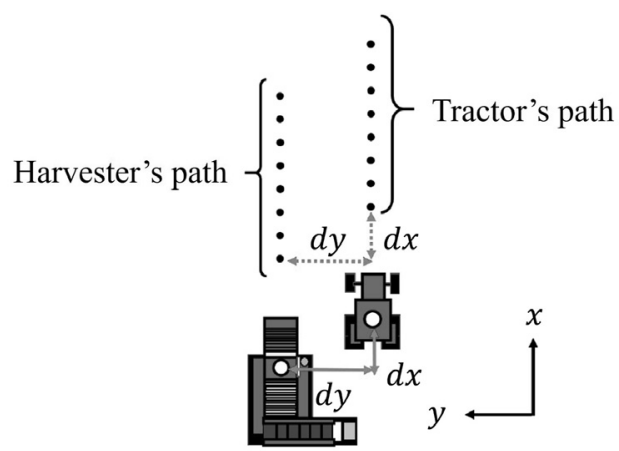

Fig. 6 Parallel travelling path

\section{3. 実機実験}

2 節で述べた自動並走システムの実装と精度検証のた めに行った実機実験について述べる. 実験は北海道河東 郡鹿追町にあるタマネギ畑 (Fig. 7) にて検証を行った.

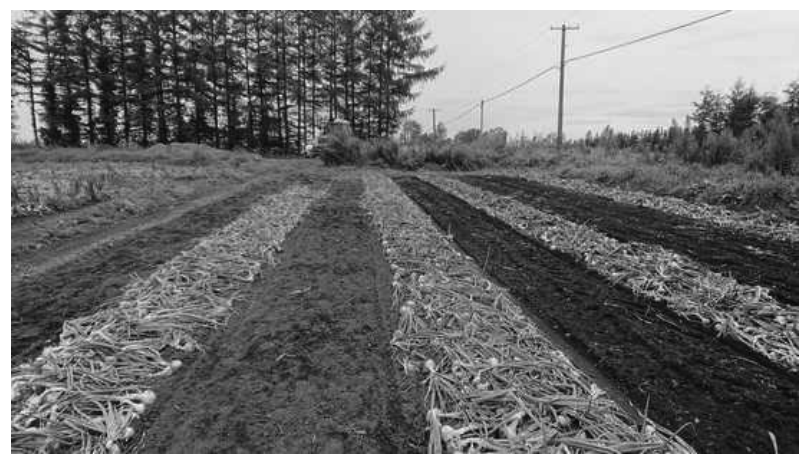

Fig. 7 Experimental field

\section{1 実験装置}

本システムにおいて実際に使用した機器について説明 する。トラクタはヤンマー製のエコトラ EG105 (Fig. 8, Table 1) を改造した車両を使用した。前輪が車輪, 後輪 
がクローラのセミクローラタイプのトラクタである. 外 部からの指令による制御が可能であり, CAN (Control Area Network) を介して制御用 PC と車両のコントロー ラの通信を行う。また本実験では，タマネギを収納する コンテナを運ぶトレーラ (Fig. 8, Table 2) をトラク夕に 劧引させる。車両の位置情報, 方位情報を取得するセン サとして RTK-GNSS/Compass（長田電気製，SB70） を取り付けている．2機取り付けることで，センサの位 置関係より方位情報の算出が可能となっている．RTKGNSS/Compass から得られる位置情報，方位情報，速 度情報を基に操舵制御，速度制御を行う。また，本実験 で並走対象となる夕マネギ収穫機は訓子府機械工業株式 会社製のオニオンピッカーKTP-1200 (Fig. 9) を改造し た車両である，右側にタマネギを送るコンベアが装着さ れて抢り，これにより収穫したタマネギをトラクタが率 引するコンテナに収納する。

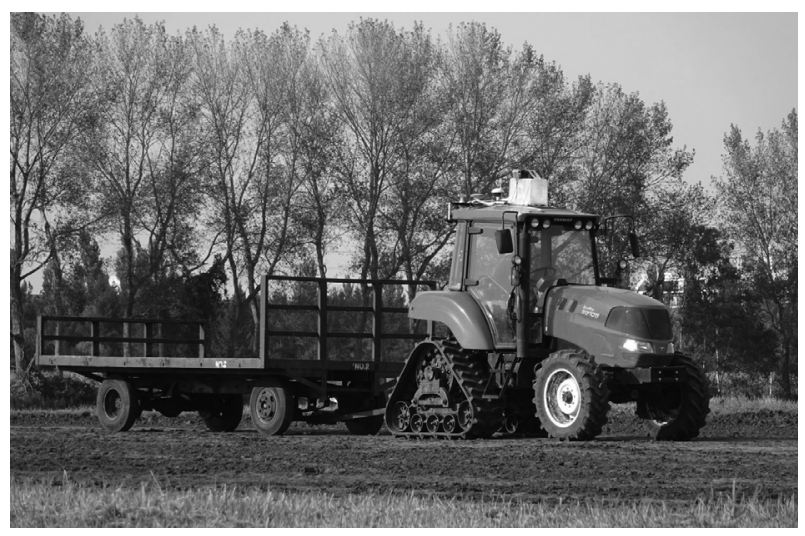

Fig. 8 Tractor and trailer

Table 1 Specification of tractor

\begin{tabular}{|c|c|c|}
\hline \multirow{3}{*}{ Base Size } & Length & $4260[\mathrm{~mm}]$ \\
\cline { 2 - 3 } & Width & $1805[\mathrm{~mm}]$ \\
\cline { 2 - 3 } & Height & $2705[\mathrm{~mm}]$ \\
\hline \multicolumn{2}{|c|}{ Mass } & $3840[\mathrm{~kg}]$ \\
\hline \multicolumn{2}{|c|}{ Wheel Base } & $2.4[\mathrm{~m}]$ \\
\hline Minumum Turning Radius & $3.9[\mathrm{~m}]$ \\
\hline
\end{tabular}

Table 2 Specification of trailer

\begin{tabular}{|c|c|c|}
\hline \multirow{2}{*}{ Base Size } & Length & $4900[\mathrm{~mm}]$ \\
\cline { 2 - 3 } & Width & $2600[\mathrm{~mm}]$ \\
\cline { 2 - 3 } & Height & $1900[\mathrm{~mm}]$ \\
\hline \multicolumn{2}{|c|}{ Mass } & $1560[\mathrm{~kg}]$ \\
\hline \multicolumn{2}{|c|}{ Wheel Base } & $3.1[\mathrm{~m}]$ \\
\hline \multicolumn{2}{|c|}{ Connector Length } & $2.4[\mathrm{~m}]$ \\
\hline
\end{tabular}

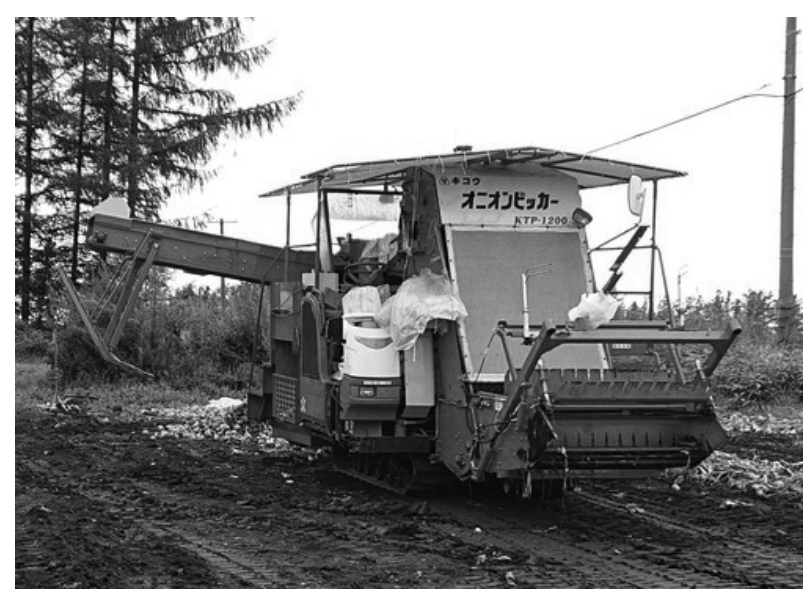

Fig. 9 Onion harvester

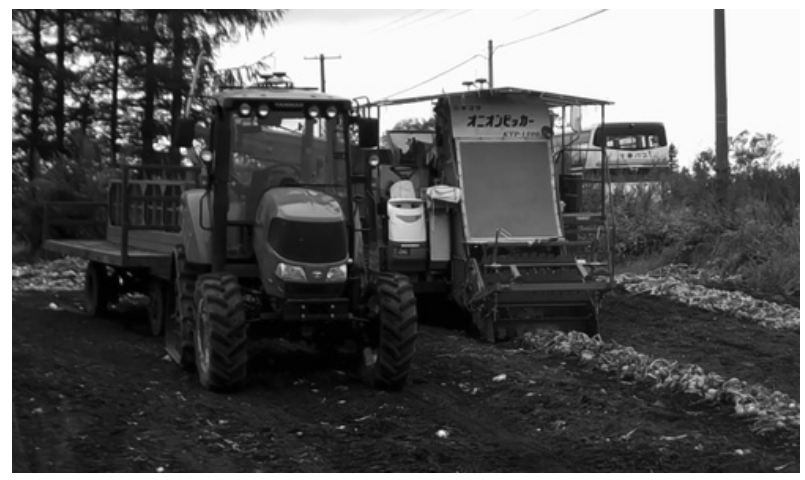

Fig. 10 Autonomous parallel travelling

Table 3 Control parameters

\begin{tabular}{|c|c||c|c|}
\hline$K_{s}$ & 0.12 & $K_{p}$ & 0.6 \\
\hline$\delta$ & 0.08 & $K_{d}$ & 0.3 \\
\hline$\eta$ & 0.03 & - & - \\
\hline
\end{tabular}

\section{2 タマネギ収穫機との並走実験結果}

GNSS/Compass の情報をタイムスタンプから補正を 行い, 操舵制御にスライデイングモード制御, 速度制 御に PD 制御を用いてタマネギ収穫機との並走を行っ た. Fig. 10 に自動並走の様子を示す. 収穫機の速度を $0.3 \mathrm{~m} / \mathrm{s}$, 制御ゲインを Table 3 に示す值に設定し, 実験 を行った。タマネギ収穫機およびトラクタ間の縦偏差, 横偏差，迴頭角偏差の時間変化を Fig. 12, Fig. 13 拈よ びFig. 14 に示す。実験結果より, 縦偏差は $\pm 0.11 \mathrm{~m}$ 以 内, 横偏差は $\pm 0.07 \mathrm{~m}$ 以内, 角度偏差は \pm 2 度以内の走 行誤差となった。 シュータとコンテナの関係から縦・横方 向に $\pm 0.15 \mathrm{~m}$ 以上の余裕があり, 実際にタマネギの自動 収穫・収納を行いながらの実験であったが，取りこぼし もなく，自動収穫を行ううえで問題のない精度であった。 


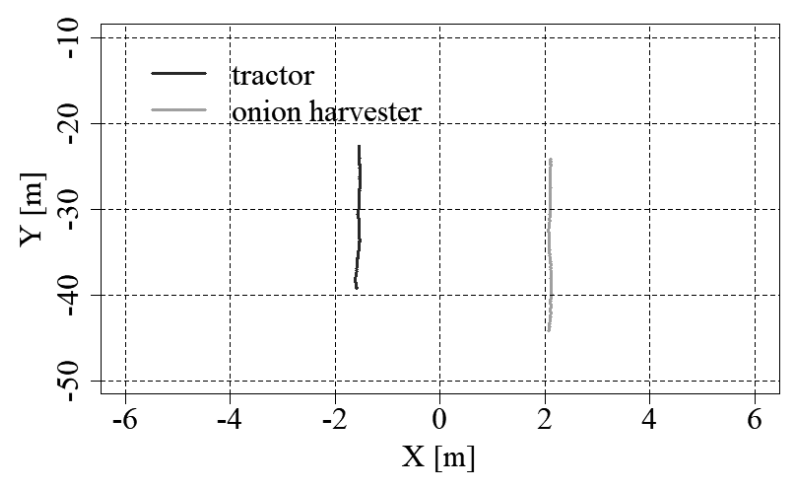

Fig. 11 Trajectries of the tractor and the onion harvester

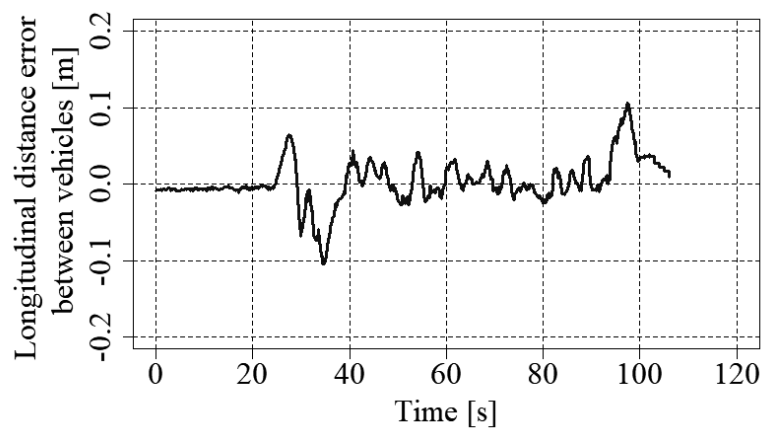

Fig. 12 Longitudinal error between the tractor and the onion harvester

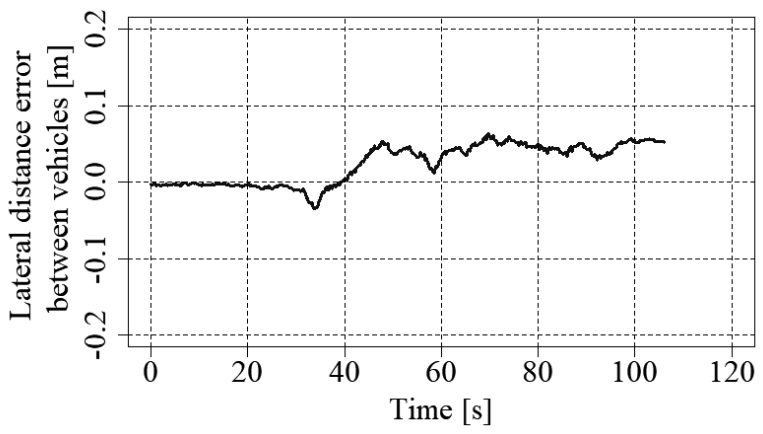

Fig. 13 Lateral error between the tractor and the onion harvester

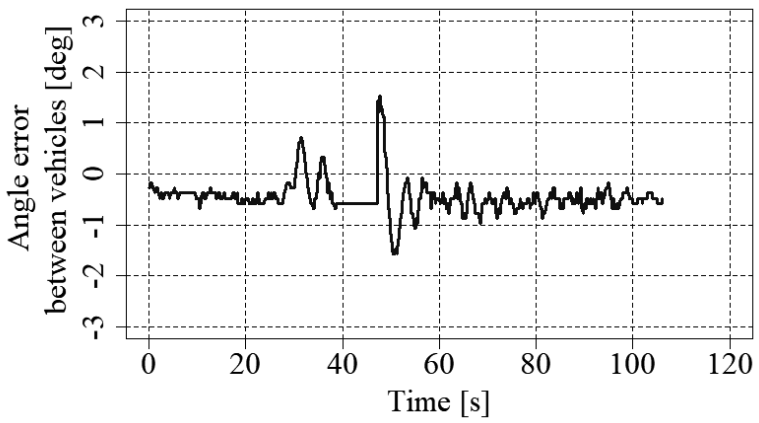

Fig. 14 Orientation error between the tractor and the onion harvester

\section{4. 結言}

本論文では，タマネギ収獲の効率化のためにタマネギ 収獲機とトラクタが並走する方法を提案した。収獲速度 を $0.3 \mathrm{~m} / \mathrm{s}$ で実験を行った結果, 縦偏差 $\pm 0.11 \mathrm{~m}$ 以内, 横
偏差 $\pm 0.07 \mathrm{~m}$ 以内, そして角度偏差は \pm 2 度以内の走行 誤差となり，位置関係をおよそ保ったまま並走できるこ とを確認した.

\section{謝 辞}

本研究は, 農研機構生研支援センター「革新的技術開 発緊急展開事業（うち人工知能未来農業創造プロジェク ト）」の支援を受けて行ったものであり，厚く感謝の意 を表します。

\section{参 考文 献}

[1] 農林水産省：野菜の消費をめぐる状況について (2013)

[2] 農林水産省：野菜の消費をめぐる情勢 (2016)

[3] 森田, 青山, 吉本, 深尾, 村上: タマネギ収穫機の自動 操舵制御; 計測自動制御学会制御部門 第 5 回制御部門マ ルチシンポジウム論文集, Su31-4 (2018)

[4] 森田, 吉本, 深尾, 村上: タマネギ収穫機の自動操舵制 御; 計測自動制御学会関西支部・システム制御情報学会 若手研究発表会, B1-3 (2019)

[5] 水島, 野口, 松尾: GPS を利用した車両方位計測法; 農業 機械学会誌, Vol. 66, No. 4, pp. 136-144 (2004)

[6] 飯田, 山田: GPS とジャイロを用いた無人コンバインによ る稲収穫; 農業機械学会誌, Vol. 68, No. 6, pp. 138-143 (2006)

[7] 倉鋪, 深尾, 大須賀, 石山, 竹原, 今井 : 不整地を想定 した移動ロボットのロバスト制御; 日本機械学会論文集 (C 編), Vol. 74, No. 747, pp. 2705-2712 (2008)

[8] 吉田, 杉町, 深尾: トラックの Path Following 制御に 基く自動運転; 日本機械学会論文集 (C 編), Vol. 77, No. 783, pp. 165-175 (2011)

[9] Y. Kanayama, Y. Kimura, F. Miyazaki and T. Noguchi: A stable tracking control method for an autonomous mobile robot; Proc. IEEE Int. Conf. Robotics E Automation (1990)

[10] C. Edwards and S. Spurgeon: Sliding Mode Control Theory And Applications (Series in Systems and Control), Taylor \& Francis (1998)

[11] 野波, 田：スライディングモード制御-非線形ロバスト 制御の設計理論-, コロナ社 (1994)

\section{著者 略歴}

小野山博品 (正会員)

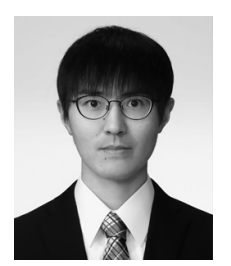

2016 年京都大学大学院農学研究科地域 環境科学専攻博士課程修了. 同年立命館大 学総合科学技術研究機構助教, 2019 年同 大学総合科学技術研究機構准教授となり現 在に至る。農業情報工学および農業機械の ロボット化に関する研究に従事。博士（農 学). IEEE, 日本土畩肥料学会の会員. 
捾享柊实

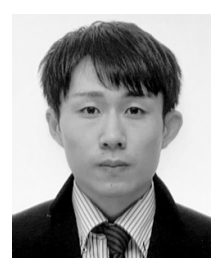

2020 年立命館大学理工学部卒業, 同年 同大学大学院理工学研究科博士前期課程に 進学し, 現在に至る。キャベッ収穫機掞よ びタマネギ収穫機のロボット化に関する研 究に従事.

鏧㔖裕也

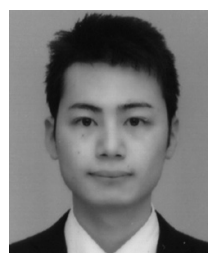

2020 年立命館大学大学院理工学研究科 博士前期課程修了, 修士 (工学) .

籐苗笑志

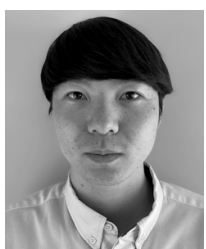

2020 年立命館大学大学院理工学研究科 博士前期課程修了, 修士（工学）。

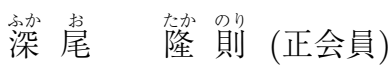

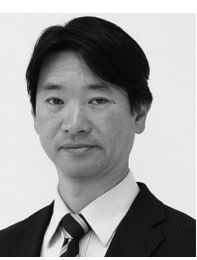

1992 年京都大学工学部航空工学科卒業, 1994 年同大学大学院工学研究科応用シス テム科学専攻修士課程修了, 1996 年同大 学院博士後期課程中退. 同年同大学院助手, 2004 年神戸大学工学部助教授, 2015 年立 命館大学理工学部教授, 2020 年東京大学 大学院情報理工学系研究科教授となり，現在に至る。2001 2003 年米国カーネギーメロン大学ロボティクス研究所客員研 究員. フィールドロボティクスに関する研究に従事. 博士（情 報学)。日本機械学会, 自動車技術会, IEEEなどの会員，

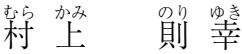

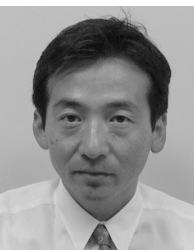

1991 年東京農工大学農学研究科修士課 程修了. 同年農林水産省農業研究センター 入所， 1999 年より北海道農業試験場に勤 務， 2000 年より 1 年間米国 CMU ロボット 工学研究所客員研究員, 北海道農業研究七 ンター水田作研究領域上席研究員を経て, 2017 年より同センター芽室研究拠点大規模畑作研究領域領 域長となり, 現在に至る。農業用ロボットなどの研究に従事. 博士 (農学)．2001 年農業機械学会研究奨励賞受賞．農業機 械学会, フルードパワーシステム学会, 農作業学会の会員. 